\title{
Hydrochemical fluxes in rainfall, throughfall, and stemflow in Pinus sylvestris var. mongolica plantation, northeast China
}

\author{
Houcai S. ${ }^{1,2 \#}$, Na G. ${ }^{3 \#}$, Siyu R. ${ }^{1}$, Jinwei Z. ${ }^{1}$, Cunyong J. ${ }^{1 *}$ and Tijiu C. ${ }^{1,3^{*}}$ \\ ${ }^{1}$ Key Laboratory of Sustainable Forest Ecosystem Management-Ministry of Education, School of Forestry, Northeast Forestry \\ University, Harbin 150040, Heilongjiang, P. R. China \\ ${ }^{2}$ Heilongjiang Mohe Forest Ecosystem National Observation and Research Station, Northeast Forestry University, Harbin 150040, \\ Heilongjiang, P. R. China \\ ${ }^{3}$ Department of Food and Environmental Engineering, East University of Heilongjiang, Harbin, 150040, Heilongjiang, P. R. China \\ \#These authors contributed equally to this work \\ Received: 05/02/2021, Accepted: 07/07/2021, Available online: 17/09/2021 \\ *to whom all correspondence should be addressed: e-mail: qucy09@nefu.edu.cn; tijiu.cai@nefu.edu.cn \\ https://doi.org/10.30955/gnj.003559
}

\section{Graphical abstract}
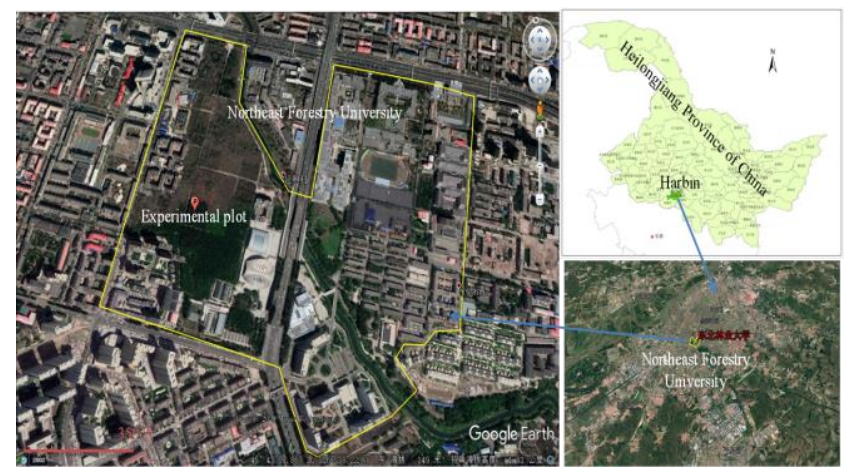

\section{Abstract}

Rainfall is one of the primary sources of chemical inputs in forest ecosystems, and the basis of forest nutrient cycling. To explore the variations of nutrient cycling and nutrient balance in rainfall redistribution process in urban forest ecosystem, we investigated the chemistry of rainfall, throughfall and stemflow in a plantation of Pinus sylvestris var. mongolica distributed in Harbin city of Northeastern China. Mean nutrient concentrations in stemflow were higher than in throughfall and rainfall. Over the growing season observation, the ions $\left(\mathrm{NO}_{3}{ }^{-}, \mathrm{PO}_{4}{ }^{3-}, \mathrm{SO}_{4}{ }^{2-}, \mathrm{Cl}+\mathrm{K}, \mathrm{Ca}\right.$ and $\mathrm{Mg}$ ) fluxes in rainfall, throughfall and stemflow were $64.021 \mathrm{~kg} \cdot \mathrm{ha}^{-1}, 44.928 \mathrm{~kg} \cdot \mathrm{ha}^{-1}$ and $15.414 \mathrm{~kg} \cdot \mathrm{ha}^{-1}$ respectively. The net throughfall and stemflow deposit was $-3.679 \mathrm{~kg} \cdot \mathrm{ha}^{-1}$, in the growing season. The ion input in precipitation, throughfall and stemflow were mainly $\mathrm{NO}_{3}^{-}$, $\mathrm{SO}_{4}{ }^{2-}$ and $\mathrm{Ca}$, and the canopy of $P$. sylvestris var. mongolica plantation can wash off $\mathrm{NO}_{3}{ }^{-}$and $\mathrm{Mg}$ in rainfall, but retain $\mathrm{PO}_{4}{ }^{3-}, \mathrm{SO}_{4}{ }^{2-}, \mathrm{Cl}^{-}, \mathrm{K}$ and $\mathrm{Ca}$ slightly. Our findings will facilitate a greater understanding of nutrient balance in canopy water fluxes in an urban area.

Keywords: urban forest, aqueous fluxes, canopy filtering, water chemistry, macronutrients input.

\section{Introduction}

The rainfall interception and redistribution by forest canopy is very important to water cycles of forest ecosystem (Sheng and Cai, 2019). It not only changes the spatial distribution of rainfall inputting in the forest (Michopoulos et al., 2018), but also alters the chemical characteristics of rainwater passing through forest canopy which accumulated nutrients by dry deposition (Lindberg et al., 1986; Lovett et al., 1993), and then affects the forest ecosystem biochemical cycles (Rodrigo et al., 2003; Sheng et al., 2015). With the intensity of global climate change, variation in rainfall patterns (amount and seasonality) will become more frequent and intense, and the changes can affect nutrient cycling in forest ecosystem (Su et al., 2019). Therefore, a comprehensive understanding of the relationship between the rainfall and nutrient cycling in forest ecosystem is crucial to explore forest water conservation function, mechanism of forest purifying water quality and quantify the ecosystem service functions.

The rainfall is an important source of nutrients in forest ecosystems (Su et al., 2019). In recent years, research on forest hydrochemical characteristics have attracted more attention (Lu et al., 2015; Lu et al., 2017; Su et al., 2019; Tan et al., 2018, 2019), and have become the hotspot in the field of forest hydrology. Over the past several decades, a large number of studies focus on rainfall redistribution by different natural forests in different regions (Wei et al., 2005; Llorens et al., 2007; Komatsu et al., 2008; Magliano et al., 2018; Nytch et al., 2019). Although some studies have explored the rainfall distribution and hydrochemistry in different types of plantation ecosystems (Crockford et al., 1996; Ma et al., 2007; Li et al., 2019), there are few studies and discussions on forest hydrochemistry in northeast China, especially on hydrochemical fluxes in an urban forest which under a complex and changeable environment. 
The Pinus sylvestris var. mongolica is listed as an important tree species for the 3-Norths Shelter Forest Program in China due to its well-adapted characteristic and resistance to drought and barren and well-adapted. The community formed by $P$. sylvestris var. mongolica has significant effects on preventing wind, stabilizing soil, improving soil moisture and nutrient (Cao et al., 2018), and plays an important role in controlling desertification and protecting the farmland (Li et al., 2015). P. sylvestris var. mongolica as the main tree species for carbon sequestration and desertification control, in addition to some research focuses on hydrological function of soil (Cao et al., 2018) and litter layer (Wang et al., 2015), there are few studies on the ecohydrologic process of the plantation ecosystems, especially in water chemistry of forest ecosystem hydrological processes (Wu et al., 2019; Michopoulos et al., 2020). So far, it has only been reported by Zhao et al. (2006) in the eastern mountains of Heilongjiang Province of China, but the hydrochemical fluxes along with rainfall redistribution process in $P$. sylvestris var. mongolica plantation ecosystem are not completely clear. Therefore, it is necessary to monitor the hydrochemical characteristics of each component in the rainfall redistribution process of $P$. sylvestris var. mongolica plantation.

Within this context, in this study, the rainfall, throughfall, and stemflow in the $P$. sylvestris var. mongolica plantation in Harbin city were monitored. Additionally, we measured the nutrient deposit of the $P$. sylvestris var. mongolica plantation to (1) analyze and evaluate the concentration of seven nutrients in rainfall, throughfall, and stemflow; and (2) to compare and evaluate nutrient deposit and nutrient exchange characteristics of the $P$. sylvestris var. mongolica plantation in an urban environment.

\section{Materials and methods}

\subsection{Site descriptions}

This study was carried out during the growing season (May to October) of 2015 within a P. sylvestris var. mongolica plantation in Northeast China. The study area was located in the Urban Forest Demonstration Base of Northeast Forestry University, in Heilongjiang Province in Northeast China $\left(126^{\circ} 37^{\prime} 15^{\prime \prime} \mathrm{E} ; 45^{\circ} 43^{\prime} 10^{\prime \prime} \mathrm{N}\right)$. The Base is located in the urban area of Harbin, covering an area of 44 $\mathrm{hm}^{2}$, in which the $P$. sylvestris var. mongolica plantation area is about $0.5 \mathrm{hm}^{2}$ (Figure 1). Harbin has a temperate continental monsoon climate, with an average annual temperature of $3.5^{\circ} \mathrm{C}$. The average annual precipitation (1995-2010) is $500.1 \mathrm{~mm}$, and the precipitation is mainly concentrated from June to August, accounting for $60 \sim 70 \%$ of the annual precipitation. The average annual water surface evaporation is $726 \mathrm{~mm}$. The soil of the site was Haplic Phaeozem (FAO) and the $\mathrm{pH}$ value was about 6.48.

The $P$. sylvestris var. mongolica plantation was formed in 1957 with two-year seedling cavernous colonization. After more than 50 years of tending and management, the forest canopy density was 0.80 , the tree heights were 17.5 $\pm 1.6 \mathrm{~m}$ (mean \pm s.d.) with $20.1 \pm 1.2 \mathrm{~cm}$ diameter at breast height $(\mathrm{DBH})$, and density was 1140 tree/ha. The understory species include Lonicera maackii, Rhamnus ussuriensis, Ixeris polycephala, and the sapling of Fraxinus mandshurica, Phellodendron amurense etc., and the ground coverages is $10 \%-50 \%$.

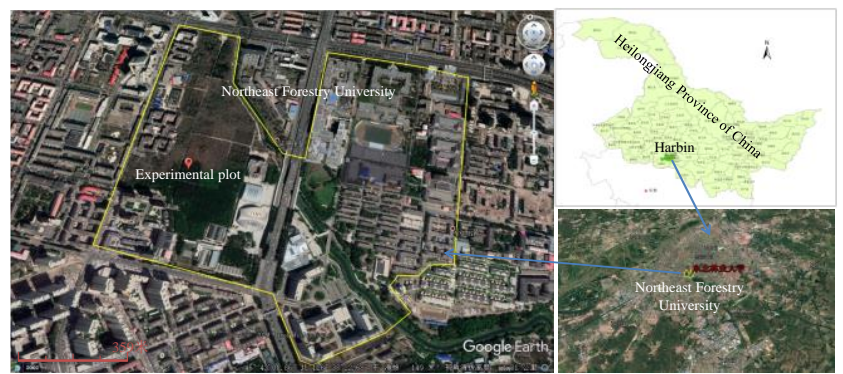

Figure 1. Locations of the study area and observation plot.

\subsection{Sampling design}

We collected samples from every rainfall event in the growing season of 2015 . The precipitation $(P)$ was monitored using a tipping-bucket rain gauge (HOBO RG3$\mathrm{M}, 0.2 \mathrm{~mm} / \mathrm{tip})$, which was installed on the roof platform ( $300 \mathrm{~m}$ away from the sample site). There are also three collectors (cross sectional area is $314.16 \mathrm{~cm}^{2} /$ collector, the same below) located in an open area adjacent to the study plot to sample for chemical analysis.

To measure throughfall, we set up a $20 \mathrm{~m} \times 20 \mathrm{~m}$ observation sample plot in the central area of the $P$. sylvestris var. mongolica plantation. The throughfall (Tf) was collected and measured using 13 collectors across the plot. The collectors are crossed at the center of the plot, and the distance between any adjacent collectors is $2 \mathrm{~m}$ in the same direction. Throughfall collectors were set up 50 $\mathrm{cm}$ above the forest floor to avoid understory effects and were evenly distributed at fixed positions throughout the growing period. At the end of each rainfall, the volume of rainwater in every gauge was immediately measured and the samples were collected for chemical analysis. Measurements unit was $\mathrm{mm}$, equivalent of 1 liter of the water per square meter.

The stemflow $(S f)$ was collected using a halved rubber collar, which spirally wrapped around each selected tree stem (Sheng et al., 2019). The bottom part of the rubber collar was kept intact, and the collected stemflow was funneled into a plastic jug nearby the base of stem (Su et al., 2019). Due to the similar diameter at breast height of trees in the plantation, 5 typical (non-dominant or pressed wood) $P$. sylvestris var. mongolica were selected as the monitored standard trees representing the mean growth of the plantation. After each rainfall, we immediately measured the volume of rainwater and collected samples for chemical analysis.

\subsection{Chemical analysis}

The collected samples after each rainfall event were firstly placed in clean polyethylene bottles. Soon after, the samples were rapidly transported to the laboratory where they were filtered using qualitative filter paper and then were divided into two parts. One sample was directly used to measure the concentrations of anions (i.e., $\mathrm{PO}_{4}{ }^{3-}, \mathrm{NO}_{3}{ }^{-}$, 
$\mathrm{SO}_{4}{ }^{2-}$ and $\mathrm{Cl}^{-}$) by ion chromatograph (Metrohm 883), and the other sample was adjusted to a $\mathrm{pH}$ of 1 2 with highpurity grade (GR) nitric acid for measuring the concentrations of metal elements (i.e., $\mathrm{K}, \mathrm{Ca}$ and $\mathrm{Mg}$ ) by atomic absorption spectrometer (Thermo Scientific ICE3500).

\subsection{Data analysis}

The stand throughfall depth $(\mathrm{mm})$ was calculated by the average value of the 13 throughfall collectors. The stand stemflow depth $(\mathrm{mm})$ can be estimated according to the stemflow of standard trees, the tree number and the area of the studied plot (Equation (1)).

$$
S f=\frac{N \cdot S}{A \cdot 10^{4}}
$$

where $S f$ is the stemflow volume $(\mathrm{mm}), N$ is the trees number in the plot, $S$ is the average stemflow value $(\mathrm{mL})$ of the 5 standard trees, and $A$ is the area of the studied plot $\left(\mathrm{m}^{2}\right)$.

The rainfall interception $(I)$ was estimated using the wetcanopy water balance equation as follows:

$$
I=P-T f-S f
$$

On a rainfall event basis, the volume-weighted mean $\mathrm{E}$ (VWME) of rainfall, throughfall and stemflow were calculated according to Equation (3). The input of a given nutrient was estimated according to Equation (4). See reference (Su et al., 2019) for details.

$$
V W M_{E}=\frac{\sum_{n=1}^{i} C_{i, E} \cdot V_{i, E}}{\sum_{n=1}^{i} V_{i, E}}
$$

where $V W M_{E}$ represents the mean concentration of a chemical element or compound $\left(\mathrm{mg} \cdot \mathrm{L}^{-1}\right), C_{i, E}$ represents the concentration at collector $i$ for event $E\left(\mathrm{mg} \cdot \mathrm{L}^{-1}\right), V_{i}, E$ represents the rainfall, throughfall, and stemflow amount at collector $i$ for event $E(\mathrm{~mm})$.

$$
F=\frac{V W M_{E} \cdot V}{100}
$$

where $F$ represents the input of a certain element or compound $\left(\mathrm{kg} \cdot \mathrm{ha}^{-1}\right)$, and $V$ represents the total volume of bulk precipitation, throughfall or stemflow $(\mathrm{mm})$.

The total input is the sum of the solute in the throughfall and stemflow, and the difference value of the total input and rainfall input is regarded as the rainfall loading (Su et al., 2019).

Table 1. Chemical characteristics of water in rainfall, throughfall and stemflow during the monitoring period. (Values represented means \pm standard error)

\begin{tabular}{cccc}
\hline \multirow{2}{*}{ Chemical Variable } & \multicolumn{3}{c}{ Concentrations $\left(\mathbf{m g ~ L}^{-1}\right)$} \\
\cline { 2 - 4 } & Rainfall & Throughfall & Stemflow \\
\hline $\mathrm{NO}_{3}{ }^{-}$ & $2.793 \pm 0.622$ & $6.355 \pm 2.231$ & $10.372 \pm 2.750$ \\
\hline $\mathrm{PO}_{4}{ }^{--}$ & $0.384 \pm 0.527$ & $0.399 \pm 0.513$ & $0.558 \pm 0.892$ \\
\hline $\mathrm{SO}_{4}{ }^{-}$ & $3.529 \pm 1.753$ & $4.983 \pm 0.417$ & $6.294 \pm 2.841$ \\
\hline $\mathrm{Cl}^{-}$ & $1.518 \pm 0.701$ & $1.495 \pm 0.962$ & $3.011 \pm 1.747$ \\
\hline $\mathrm{K}$ & $1.885 \pm 0.629$ & $2.035 \pm 0.567$ & $6.846 \pm 1.882$ \\
\hline $\mathrm{Ca}$ & $4.523 \pm 1.031$ & $4.430 \pm 0.902$ & $15.465 \pm 2.140$ \\
\hline $\mathrm{Mg}$ & $0.412 \pm 0.137$ & $0.589 \pm 0.494$ & $1.340 \pm 0.110$ \\
\hline
\end{tabular}

\section{Results}

\subsection{Hydrological fluxes}

From 1 May to 31 October, there were 31 discrete rainfall events occurred. The rainfall, throughfall, and stemflow of each month are shown in Figure 2. The total rainfall during this period was $430.2 \mathrm{~mm}$, and the maximum and minimum rainfall inputs were recorded in August (159.4 $\mathrm{mm}$ ) and October $(23.5 \mathrm{~mm})$, respectively. The total throughfall was $223.1 \mathrm{~mm}$, and the proportion occurring as throughfall ranged from $33.19 \%$ to $78.17 \%$ with a mean of $51.86 \%$. The total stemflow amount was only $34.6 \mathrm{~mm}$, accounting for $4.68 \%$ of rainfall in May, and $10.16 \%$ in August, which accounted for a total of $8.04 \%$ of total rainfall across the study period. The total interception loss was $172.5 \mathrm{~mm}$, representing $40.10 \%$ of total rainfall (Figure 2).

\subsection{Chemistry of canopy water fluxes}

The volume-weighted mean concentration of all solutes in the rainfall, throughfall, and stemflow are shown in Table 1. Most of the elements and compounds were more concentrated in throughfall and stemflow, except for $\mathrm{Cl}^{-}$and $\mathrm{Ca}$, whose concentration in rainfall were slightly larger than those in throughfall, and lower than those in stemflow.

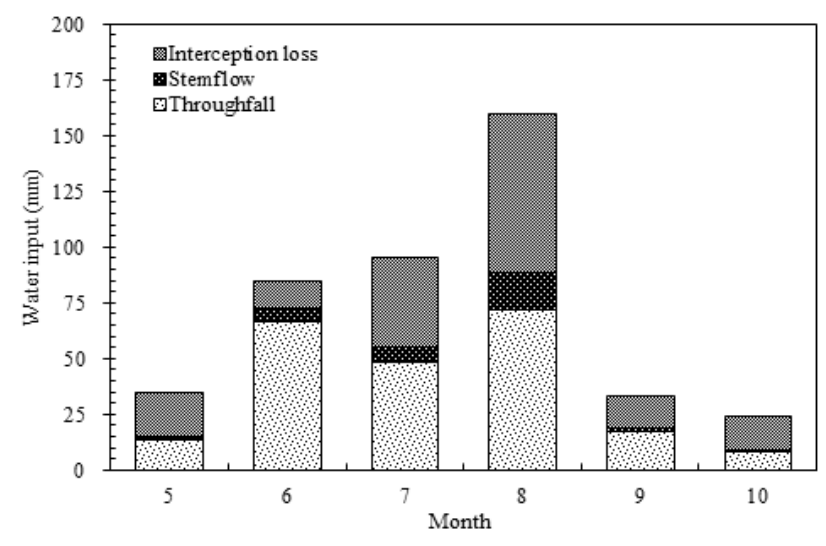

Figure 2. Monthly input of water via throughfall, stemflow and interception loss.

Among the various nutrients in rainfall, the maximum and minimum values of concentration were $4.508 \mathrm{mg} \cdot \mathrm{L}^{-1}$ (Ca) 
and $0.266 \mathrm{mg} \cdot \mathrm{L}^{-1}(\mathrm{Mg})$, respectively, and the maximum is 16.95 times greater than the minimum. The concentrations of the solutes in rainfall showed $\mathrm{a}$ descending order as $\mathrm{Ca}>\mathrm{SO}_{4}{ }^{2-}>\mathrm{NO}_{3}{ }^{-}>\mathrm{K}>\mathrm{Cl}^{-}>\mathrm{Mg}>\mathrm{PO}_{4}^{3-}$.

Compared with the bulk precipitation, the ions concentrations in the throughfall has been increased to varying degrees just as $\mathrm{NO}_{3}{ }^{-}$increased by $\left.127.52 \%\right), \mathrm{PO}_{4}{ }^{3-} 3.72 \%$, $\mathrm{SO}_{4}{ }^{2-} 41.21 \%, \mathrm{~K} 7.97 \%$ and $\mathrm{Mg} 76.36 \%$ respectively. The concentrations of all 7 solutes were also greater in stemflow than in throughfall. Compared to throughfall, $\mathrm{NO}_{3}{ }^{-}, \mathrm{PO}_{4}{ }^{3-}, \mathrm{SO}_{4}{ }^{2-}, \mathrm{Cl}^{-}, \mathrm{K}, \mathrm{Ca}$ and $\mathrm{Mg}$ were enhanced in stemflow by $63.20 \%, 39.98 \%, 26.30 \%, 101.40 \%, 236.37 \%$, $249.12 \%$ and $354.47 \%$, respectively (Table 1 ).

\subsection{Temporal dynamics of water fluxes}

The nutrient concentration responding to the rainfall, throughfall, and stemflow are shown as volumeweighted mean solute concentrations for each monthly period (Figure 3). For rainfall, the highest concentration of the 7 solutes is $6.821 \mathrm{mg} \cdot \mathrm{L}^{-1}(\mathrm{Ca})$, and the lowest value is 0 $\mathrm{mg} \cdot \mathrm{L}^{-1}\left(\mathrm{PO}_{4}{ }^{3-}\right)$. Although the concentration of $\mathrm{PO}_{4}{ }^{3-}$ is low, but the changes are huge and special, especially the concentration of $\mathrm{PO}_{4}{ }^{3-}$ in July and September both are 0 $\mathrm{mg} \cdot \mathrm{L}^{-1}$. Except $\mathrm{PO}_{4}{ }^{3-}$, the highest concentration of the other 6 solutes in the rainfall, appeared for $\mathrm{NO}_{3}{ }^{-}$in June, $\mathrm{SO}_{4}{ }^{2-}$ and $\mathrm{Ca}$ in October, and $\mathrm{Cl}^{-}, \mathrm{K}$ and $\mathrm{Mg}$ in September. In terms of the lowest value, $\mathrm{Mg}, \mathrm{Cl}^{-}, \mathrm{K}, \mathrm{SO}_{4}{ }^{2-}$ and $\mathrm{Ca}$ appeared in May, and $\mathrm{NO}_{3}{ }^{-}$appeared in October. Among the concentration of other 6 solutes, $\mathrm{NO}_{3}{ }^{-}$had the highest coefficient variation ( $\mathrm{CV}, 73.8 \%$ ) while $\mathrm{Ca}$ had the lowest CV (26.5\%) (Table 2). The CVs of these 6 solutes ranked as follows: $\mathrm{NO}_{3}{ }^{-}>\mathrm{Mg}>\mathrm{Cl}^{-}>\mathrm{SO}_{4}{ }^{2-}>\mathrm{K}>\mathrm{Ca}$.

In throughfall, $\mathrm{NO}_{3}{ }^{-}$has the highest concentration (7.542 $\left.\mathrm{mg} \cdot \mathrm{L}^{-1}\right), \mathrm{PO}_{4}{ }^{3-}$ has the lowest concentration $\left(0 \mathrm{mg} \cdot \mathrm{L}^{-1}\right)$, and the concentration of $\mathrm{PO}_{4}{ }^{3-}$ in July, August and September are all $0 \mathrm{mg} \cdot \mathrm{L}^{-1}$. Among the 6 solutes (except $\mathrm{PO}_{4}{ }^{3-}$ ), $\mathrm{Mg}$ had the highest $\mathrm{CV}(82.0 \%)$ while $\mathrm{K}$ had the lowest $\mathrm{CV}$ (41.9\%) (Table 2). The CVs of these 6 solutes showed the following trend: $\mathrm{Mg}>\mathrm{Cl}^{-}>\mathrm{NO}_{3}>\mathrm{Ca}>\mathrm{SO}_{4}{ }^{2-}>\mathrm{K}$, which is quite different from that in rainfall.

Table 2. The CVs of the solutes in in rainfall, throughfall and stemflow

\begin{tabular}{cccccccc}
\hline \multirow{2}{*}{ Parameter } & \multicolumn{7}{c}{$\mathbf{C V}(\%)$} \\
\cline { 2 - 8 } & $\mathbf{N O}_{3}{ }^{-}$ & $\mathbf{P O}^{{ }^{3-}}$ & $\mathbf{S O}^{{ }^{-2}}$ & $\mathbf{C l}$ & $\mathbf{K}$ & $\mathbf{C a}$ & $\mathbf{M g}$ \\
\hline Rainfall & 73.8 & - & 57.9 & 60.9 & 53.7 & 26.5 & 68.3 \\
\hline Throughfall & 52.7 & - & 42.1 & 54.2 & 41.9 & 46.3 & 82.0 \\
\hline Stemflow & 63.0 & 109.2 & 64.2 & 61.5 & 47.8 & 42.3 & 42.6 \\
\hline
\end{tabular}
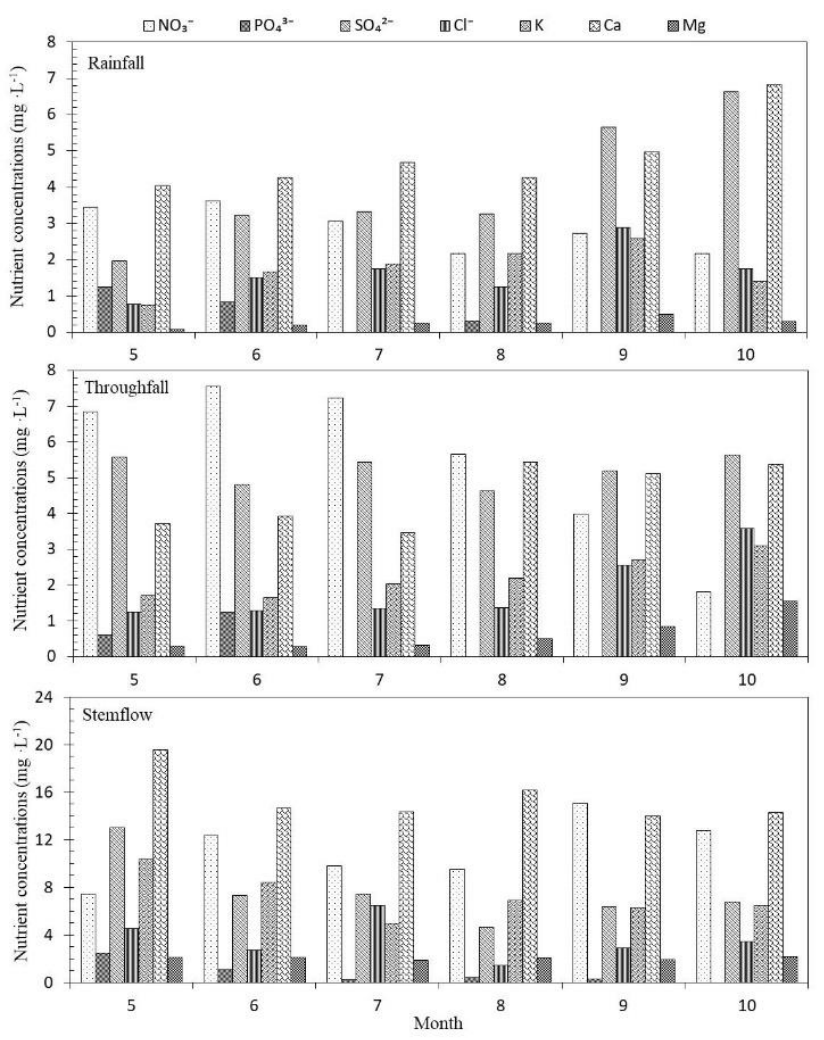

Figure 3. Monthly concentrations of solutes in rainfall, throughfall and stemflow.

For stemflow, the maximum and minimum values of concentration were $19.569 \mathrm{mg} \cdot \mathrm{L}^{-1}(\mathrm{Ca})$ and $0.106 \mathrm{mg} \cdot \mathrm{L}^{-1}$ $\left(\mathrm{PO}_{4}{ }^{3-}\right)$, respectively, and the maximum is 184.61 times greater than the minimum. The $\mathrm{PO}_{4}{ }^{3-}$ concentration each month was not negligible. Among 7 solutes, $\mathrm{PO}_{4}{ }^{3-}$ had the highest CV (109.2\%) while Ca had the lowest CV (42.3\%) in terms of concentration (Table 2). The CVs of these 7 solutes ranked as follows: $\mathrm{PO}_{4}{ }^{3-}>\mathrm{Cl}^{-}>\mathrm{SO}_{4}{ }^{2-}>\mathrm{NO}_{3}{ }^{-}>\mathrm{K}>$ $\mathrm{Mg}>\mathrm{Ca}$.

\subsection{Nutrient input}

We observed large variation in nutrient inputs within the $P$. sylvestris var. mongolica plantation. The inputted nutrient volume and rainfall loading are shown in Table 3. The highest inputted nutrient via throughfall was $\mathrm{NO}_{3}{ }^{-}$, while Ca was the largest input for rainfall and stemflow. In rainfall, the input of 7 solutes during the study period is $64.021 \mathrm{~kg} \cdot \mathrm{ha}^{-1}$, of which the inputs of $\mathrm{Ca}, \mathrm{SO}_{4}{ }^{2-}$ and $\mathrm{NO}_{3}{ }^{-}$ were relatively large and accounted for the total rainfall input by $30.39 \%, 23.71 \%$ and $18.77 \%$, respectively.

The total input of 7 solutes fluxes during the study period is $60.342 \mathrm{~kg} \cdot \mathrm{ha}^{-1}$, and the sequence of the 7 solute input fluxes was: $\mathrm{NO}_{3}{ }^{-}>\mathrm{Ca}>\mathrm{SO}_{4}{ }^{2-}>\mathrm{K}>\mathrm{Cl}^{-}>\mathrm{Mg}>\mathrm{PO}_{4}{ }^{3-}$ (Table 3).. During the study period, the rainfall loading of 7 solutes fluxes is $-3.679 \mathrm{~kg} \cdot \mathrm{ha}^{-1}$, and the amount of rainfall loading are sorted from largest to smallest as $\mathrm{NO}_{3}{ }^{-}>\mathrm{Mg}>$ $\mathrm{PO}_{4}{ }^{3-}>\mathrm{K}>\mathrm{SO}_{4}{ }^{3-}>\mathrm{Cl}^{-}>\mathrm{Ca}$. During the interaction of rainfall and canopy layer, only $\mathrm{NO}_{3}{ }^{-}$and $\mathrm{Mg}$ were leached from the canopy, in other words, these two nutrients in rainwater were increased after passing through canopies and stems. Meanwhile, the $\mathrm{PO}_{4}{ }^{3-}, \mathrm{K} \mathrm{SO}_{4}{ }^{2-}, \mathrm{Cl}^{-}$and $\mathrm{Ca}$ were retained by the canopy, and the retained quantities were $0.571,1.199,1.885,2.154$ and $4.222 \mathrm{~kg} \mathrm{ha}^{-1}$, respectively. 
Table 3. Macronutrients fluxes in different type of water comparison to total input, and rainfall loading during the growing season

\begin{tabular}{|c|c|c|c|c|c|c|c|}
\hline \multirow{2}{*}{ Parameter } & \multicolumn{7}{|c|}{ Nutrient Input (kg ha-1) } \\
\hline & $\mathrm{NO}_{3}^{-}$ & $\mathrm{PO}_{4}{ }^{3-}$ & $\mathrm{SO}_{4}{ }^{2-}$ & $\mathrm{Cl}^{-}$ & K & $\mathrm{Ca}$ & $\mathrm{Mg}$ \\
\hline Rainfall & 12.017 & 1.654 & 15.180 & 6.532 & 8.109 & 19.456 & 1.073 \\
\hline Throughfall & 14.179 & 0.890 & 11.117 & 3.336 & 4.541 & 9.883 & 0.982 \\
\hline Stemflow & 3.589 & 0.193 & 2.178 & 1.042 & 2.369 & 5.351 & 0.692 \\
\hline Total input & 17.768 & 1.083 & 13.295 & 4.378 & 6.910 & 15.234 & 1.674 \\
\hline Rainfall loading & 5.751 & -0.571 & -1.885 & -2.154 & -1.199 & -4.222 & 0.601 \\
\hline
\end{tabular}

\section{Discussion}

The interaction between rainfall and forest canopy can change the contents of compounds and elements (Tan et al., 2018). Forest canopy can absorb atmospheric dry deposition, especially in an urban environment. While the rainfall was redistributed by forest canopy, the processes of absorption, adsorption, and leaching occured between the rainwater and the forest canopy, which changed solute concentration in different hydrological componentsto varying degrees. In this study, the concentration of $\mathrm{PO}_{4}{ }^{3-}, \mathrm{Cl}^{-}$and $\mathrm{Ca}$ with a concentration sequence of stemflow $>$ Rainfall $>$ throughfall, at the same time, $\mathrm{NO}_{3}{ }^{-}, \mathrm{SO}_{4}{ }^{2-}, \mathrm{K}$ and $\mathrm{Mg}$ with a sort order of stemflow > throughfall>rainfall. Those orders do not exactly agree with the results of stemflow $>$ throughfall $>$ rainfall in previous studies (Sheng et al., 2015; Lu et al., 2015; Lu et al., 2017), but being consistent with the results of some recent studies. For example, in the hydrological process of evergreen and deciduous broad-leaved mixed forest, the concentration of $\mathrm{NO}_{3}{ }^{-}$followed the order of stemflow > rainfall > throughfall, for $\mathrm{Ca}$ and $\mathrm{Cl}^{-}$, the orders became stemflow > throughfall > rainfall, while the order of $\mathrm{Mg}$ and $\mathrm{K}$ concentrations are consistent with this study (Su et al., 2019). In the secondary deciduous broad-leaved forest, the concentration rank of $\mathrm{K}$ in different hydrological component is consistent with this research, and $\mathrm{Ca}$ is: stemflow > throughfall > rainfall (Zhang et al., 2019). However, in the Pinus tabulaeformis plantation, even the same solute in different hydrological component has different pattern at different stages of growth (Li et al., 2019). Although stemflow has low quantities of water, it is important for plant growth, especially in arid and semiarid areas (Carlyle-Moses et al., 2018; Liu et al., 2019; Li et al., 2020). Previous studies have shown that the concentration characteristics of throughfall and stemflow depend on the interaction between atmospheric deposition and plants (Corti et al., 2019), and are affected by rainfall characteristics (Zhang et al., 2019), solute chemical activity and plant physiological characteristics (Tobón et al., 2004; Van Stan II et al., 2015). Normally, the compounds and elements concentrations in stemflow are higher than in throughfall (Su et al., 2019). This is due to the sufficiently long residence times of the intercepted precipitation on the branch surfaces, which is conducive to solutes dissolution, and the higher leachability of bark for stemflow than throughfall (Tan et al., 2018; CarlyleMoses et al., 2018). However, in this study, due to the complex and changeable urban environment, and the variable influencing factors in the hydrological process of the $P$. sylvestris var. mongolica plantation, the concentrations of solutes in rainfall are not constant. Therefore, the concentration changes of the solutes in throughfall and stemflow also have more uncertainties.

The input of nutrients by rainfall is of great significance to the nutrient cycle of forest ecosystems (Liu et al., 2019; Leandro Van Langenhove et al., 2020). In this study, the input of 7 solutes in total rainfall and total throughfall were $64.021 \mathrm{~kg} \cdot \mathrm{ha}^{-1}$ and $44.195 \mathrm{~kg} \cdot \mathrm{ha}^{-1}$, respectively, which were much larger than that in total stemflow $\left(15.414 \mathrm{~kg} \cdot \mathrm{ha}^{-1}\right)$. The rainfall loading of 7 solutes fluxes is $3.679 \mathrm{~kg} \cdot \mathrm{ha}^{-1}$, and the rainfall loading of each solute is different. Only the rainfall loading of $\mathrm{NO}_{3}{ }^{-}$and $\mathrm{Mg}$ are positive, and the others are all negative. The result indicates that the $P$. sylvestris var. mongolica plantation in Harbin can retain $\mathrm{SO}_{4}{ }^{2-}, \mathrm{PO}_{4}{ }^{3-}, \mathrm{K}_{,} \mathrm{Cl}^{-}$and $\mathrm{Ca}$. Many previous studies have found that the rainfall loading of the same solute in hydrological process has different results according to different forest types in different regions. For example, in the evergreen and deciduous broad-leaved mixed forest (Shennongjia, Hubei province, China), the rainfall loading of $\mathrm{NO}_{3}^{-}$and $\mathrm{NH}_{4}{ }^{+}$are negative, and the rainfall loading of $\mathrm{Cl}^{-}, \mathrm{SO}_{4}{ }^{2-}, \mathrm{K}, \mathrm{Ca}$ and $\mathrm{Mg}$ are all positive (Su et al., 2019). In the subtropical evergreen and deciduous broad-leaved mixed forest (The Mau Lancaster region, southwest China), the rainfall loading of $\mathrm{Na}$ and $\mathrm{NH}_{4}{ }^{+}$are negative, the $\mathrm{Cl}^{-}, \mathrm{SO}_{4}{ }^{2-}, \mathrm{NO}_{3}{ }^{-}, \mathrm{K}, \mathrm{Ca}$ and $\mathrm{Mg}$ are all positive (Lu et al., 2015), and except for $\mathrm{NO}_{3}^{-}$, it is consistent with the results of Su et al. (2019). In Pinus densata natural forest of southeast Tibet, the rainfall loading of $\mathrm{N}$ is negative, the $\mathrm{P}, \mathrm{S}, \mathrm{K}, \mathrm{Ca}$ and $\mathrm{Mg}$ are all positive (Lu et al., 2017). The rainfall loading of $\mathrm{Ca}$ in broad-leaved korean pine forest (Xiaoxing'an Mountains) is consistent with all above, but in the secondary deciduous broad-leaved forest (Changbai Mountains) (Zhang et al., 2019) and in the secondary birch forest (Xiaoxing'an Mountains) are the opposite, negative (Sheng et al., 2015). In this study, the ions retained by $P$. sylvestris var. mongolica canopy, probably results from the particulate matter (PM) in the urban atmosphere, just as Berger et al. (2008) reported that the suspended pollen is a vital factor of influencing the flux of $\mathrm{K}^{+}$. Urban forests have been proven to be efficient PM collectors and to improve air quality (Xu et al., 2019). PM has strong adsorption and elements such as $\mathrm{Ca}, \mathrm{Mg}$ and $\mathrm{K}$ are mainly found in the particles with large diameters. Therefore, the throughfall and stemflow contain a lot of particulate matter. When we filter the water for measuring the 
concentrations of ions, the large particles will be retained by the filter paper, thus reducing the ion concentration in the water. This explanation can probably account for the lower fluxes of $\mathrm{K}+$ in the throughfall plus stemflow than that in rainfall, a finding not very common in literature. All those factors led to the input of 7 solutes by total rainfall, throughfall and stemflow in this study are all dominated by $\mathrm{NO}_{3}{ }^{-}, \mathrm{SO}_{4}{ }^{2-}$ and $\mathrm{Ca}$, and the sum of total input by these three solutes accounts for more than $69 \%$ of the total inputs sum of 7 solutes.

This article has carried out observation and research on the hydrological process of $P$. sylvestris var. mongolica plantation in an urban area. However, due to the randomness of rainfall events, the complex environment of city, human activities and other factors have a greater impact on forest hydrochemical process. Therefore, longterm situ observations and more research are needed to verify the conclusions in this study using only one growing season data. In particular, the compounds such as $\mathrm{SO}_{4}{ }^{2-}$, $\mathrm{PO}_{4}{ }^{3-}$ and $\mathrm{Cl}^{-}$, which have been less studied in the past, as well as hydrochemical fluxes in solid precipitation (eg. snow) needs to be further studied in detail.

\section{Conclusion}

This study of 7 nutrient solutes in open field rainfall and its interaction with forest cover provides new results on nutrient flux in $P$. sylvestris var. mongolica plantation ecosystems. Throughfall and stemflow composition is highly influenced by forest cover. Nutrient concentrations were greatest for stemflow, followed by throughfall and rainfall. Rainfall contributed significantly to nutrient input, some fluxes might not be modified or even decreased $\left(\mathrm{PO}_{4}{ }^{3-}, \mathrm{K}, \mathrm{SO}_{4}{ }^{2-}, \mathrm{Cl}^{-}\right.$and $\left.\mathrm{Ca}\right)$, whereas some others might be considerably increased $\left(\mathrm{NO}_{3}{ }^{-}, \mathrm{Mg}\right)$. Although here data just collected and analyzed for one growing season, the study gives evidence toward rainfall being an important nutrient source within the $P$. sylvestris var. mongolica plantation. Further studies are needed to explore the characteristic of more nutrient fluxes during rainfall redistribution process.

\section{Acknowledgments}

We gratefully acknowledge the Heilongjiang Mohe Forest Ecosystem National Observation and Research Station for their assistance in hydrochemical analysis of samples. This work was supported by the Natural Science Foundation of Heilongjiang Province of China (LH2020C032), and by the Fundamental Research Funds for the Central Universities (2572018BA10).

\section{References}

Berger T.W., Untersteiner H., Schume H. and Jost G. (2008). Throughfall fluxes in a secondary spruce, a beech and a mixed spruce beech stand. Forest Ecology and Management, 255, 605-618.

Cao G.X., Ji M., Zhu J.H., Li Y.H., Geng Q.C., Li X.G., Feng L.L., Yao C.L. and Bao R. (2018). Study on soil physical properties and hydrological functions of Pinus sylvestris var. mongolica in Hulun Buir sandy land, Journal of Inner Mongolia Forestry Science \& Technology, 44, 1-6.
Carlyle-Moses D.E., lida S., Germer S., Llorens P., Michalzik B., Nanko K., Tischer A. and Levia D.F. (2018). Expressing stemflow commensurate with its ecohydrological importance, Advances in Water Resources, 121, 472-479.

Corti G., Agnell A., Cocco S., Cardellia V., Massec J. and Courchesne F. (2019). Soil affects throughfall and stemflow under Turkey oak (Quercus cerris L.), Geoderma, 333, 43-56.

Crockford R.H., Richardson D.P. and Sageman R. (1996). Chemistry of rainfall, throughfall and stemflow in a eucalypt forest and a pine plantation in south-eastern Australia: 2. Throughfall, Hydrological Processes, 10, 1-11.

Komatsu H., Shinohara Y., Kume T. and Otsuki K. (2008). Relationship between annual rainfall and interception ratio for forests across Japan, Forest Ecology and Management, 256, 1189-1197.

Leandro Van Langenhove, Verryckt L.T., Bréchet L., Courtois E.A., Stahl C., Hofhansl F., Bauters M., Sardans J., Boeckx P., Fransen E., Peñuelas J. and Janssens I.V. (2020). Atmospheric deposition of elements and its relevance for nutrient budgets of tropical forests, Biogeochemistry, 149, 175-193.

Li L.D. (2019). Hydro-chemical characteristics and ions transfer of Pinus tabulaeformis plantation in Shanjiankou Basin, Journal of Northeast Forestry University, 47, 79-83,129.

Li L.D., Chen H.L., Ren Q.W., You H.Z. and Bi J. (2020). Hydrochemical characteristics and ion transfer of rainfall of Betula Platyphylla secondary forest in Xiaowutai Mountain, Journal of Landscape Research, 12, 57-60, 66.

Li Y., Cai T.J., Man X.L., Sheng H.C. and Ju C.Y. (2015). Canopy interception loss in a Pinus sylvestris var. mongolica forest of Northeast China, Journal of Arid Land, 7, 831-840.

Lindberg S.E., Lovett G.M., Richter D.D. and Johnson D.W. (1986). Atmospheric deposition and canopy interactions of major ions in a forest. Science 231, 141-145.

Liu Y.L., Jiang L., You C.M., Li H., Tan S.Y., Tan B. and Yang W.Q. (2019). Base Cation Fluxes from the Stemflow in Three Mixed Plantations in the Rainy Zone of Western China, Forests, 10, 1101.

Llorens P., Domingo F. (2007). Rainfall partitioning by vegetation under Mediterranean conditions. A review of studies in Europe, Journal of Hydrology, 335, 37-54.

Lovett G.M. and Lindberg S.E. (1993). Atmospheric deposition and canopy interaction of nitrogen in forests. Can. Journal of Forestry Research, 23, 1603-1616.

Lu J., Zhang S.X., Fang J.P., Yan H.A. and Li J.R. (2017). Nutrient fluxes in rainfall, throughfall and stemflow in Pinus densata natural forest of Tibetan plateau, Clean Soil Air Water, 45.

Lu X.Q., Yang W.X., Ding F.J. and Toda H. (2015). Reallocation and chemical characteristics of precipitation in a Maolan karst forest, Chinese Journal of Ecology, 34, 2115-2122.

Ma X.Q., Heal K.V., Liu A.Q. and Jarvis P.G. (2007). Nutrient cycling and distribution in different-aged plantations of chinese fir in southern china, Forest Ecology and Management, 243, 61-74.

Magliano P.N., Whitworth-Hulse J.I. and Baldi Germán. (2018). Interception, throughfall and stemflow partition in drylands: Global synthesis and meta-analysis, Journal of Hydrology, 568, 638-645.

Michopoulos P., Bourletsikas A., Kaoukis K., Daskalakou E., Karetsos G., Kostakis M., Thomaidis N.S., Pasias I.N., Kaberi H. and Iliakis S. (2018). The distribution and variability of heavy 
metals in a mountainous fir forest ecosystem in two hydrological years, Global NEST Journal, 20, 188-197.

Michopoulos P., Kostakis M., Bourletsikas A., Kaoukis K., Karetsos G., Thomaidis N.S. and Nisianakis P. (2020). The fluxes and distribution of molybdenum in a mountainous fir forest in two hydrological years, Global NEST Journal, 22, 15-21.

Nytch C.J., Meléndez-Ackerman E.J., Pérez M.E. and Ortiz-Zayas J.R. (2019). Rainfall interception by six urban trees in San Juan, Puerto Rico, Urban Ecosystem, 22, 103-115.

Rodrigo A., Avila A. and Roda E. (2003). The chemistry of precipitation, throughfall and stemflow in two holm oak (Quercus ilex L.) forests under a contrasted pollution environment in NE Spain, The Science of the Total Environment, 305, 195-205.

Sheng H.C. and Cai T.J. (2019). Influence of rainfall on canopy interception in mixed broad-leaved-Korean pine forest in Xiaoxing'an Mountains, northeastern China, Forests, 10, 248.

Sheng H.C., Cai T.J. and Ju C.Y. (2015). Element characteristics in the precipitation conversion process in Betula platyphlla forest of Xiaoxing'an Mountains, northeastern China, Journal of Beijing Forestry University, 37, 59-66.

Su L., Zhao C.M., Xu W.T. and Xie Z.Q. (2019). Hydrochemical fluxes in bulk precipitation, throughfall, and stemflow in a mixed evergreen and deciduous broadleaved forest, Forests, 10, 507.

Tan S.Y., Zhao H.R., Yang W.Q., Tan B., Ni X.Y., Yue K., Zhang Y. and Wu F.Z. (2018). The effect of canopy exchange on input of base cations in a subalpine spruce plantation during the growth season, Scientific reports, 8, 9373.

Tan S.Y., Zhao H.R., Yang W.Q., Tan B., Yue K., Zhang Y., Wu F.Z. and Ni X.Y. (2019). Forest canopy can efficiently filter trace metals in deposited precipitation in a subalpine spruce plantation, Forests, 10, 318.

Tobón C., Sevink J. and Verstraten J.M. (2004). Solute fluxes in throughfall and stemflow in four forest ecosystems in northwest Amazonia, Biogeochemistry, 70, 1-25.

Van Stan II J.T. and Pypker T.G. (2015). A review and evaluation of forest canopy epiphyte roles in the partitioning and chemical alteration of precipitation, Science of the Total Environment, 536, 813-824.

Wang Q., Sun B.P., Ding G.D., Zhao G.P., Deng J.F., Gao G.L., Wang X.X. and Li X. (2015). Hydrological effects of soil and litters in Pinus sylvestris var. mogolica plantation in Yulin, Shanxi, Journal of Northwest A \& F University (Nat. Sci. Ed), 43, 123-132.

Wei X.H., Liu S.R., Zhou G.Y. and Wang C.K. (2005). Hydrological processes in major types of Chinese forest, Hydrological Processes, 19, 63-75.

Wu J.P., Su Y.X., Chen X.Z., Liu L.Y., Sun C.H., Zhang H.O., Li Y., Ye Y.Y., Zhou X., Yang J., Wang C.Y., Zhou G.Y. and Huang N.S. (2019). Redistribution characteristics of atmospheric precipitation in different spatial levels of Guangzhou urban typical forests in southern China, Atmospheric Pollution Research, 10, 1404-1411.

Xiao Y.H., Dai L.M., Niu D.K., Tong F.C., Chen G. and Deng H.B. (2002). Influence of canopy on precipitation and its nutrient elements in broad-leaved/Korean pine forest on the northern slope of Changbai Mountain, Journal of Forestry Research, 13, 201-204.
Xu X.W., Yu X.X., Mo L., Xu Y.S., Bao L. and Lun X.X. (2019). Atmospheric particulate matter accumulation on trees: $A$ comparison of boles, branches and leaves, Journal of Cleaner Production, 226, 349-356.

Zhang N., Fan C.N., Chen S.Y., Zheng J.P. and Guo Z.L. (2019). Effects of precipitation characteristics on the distribution of four metal elements by rainfalls in a secondary deciduous broad-leaved forest, Journal of Nanjing Forestry University (Natural Sciences Edition), 43, 178-184.

Zhao Y.S., Xin Y. and Zeng F.S. (2006). Chemical Properties of Water in Pinus sylvestris var. mongolica at Eastern Mountainous Region in Heilongjiang Province, Journal of Soil and Water Conservation, 20, 175-178. 